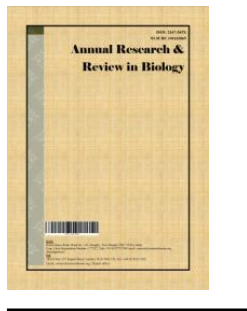

\title{
Evaluation of the response of Turkey strains to Salmonella and Newcastle vaccines
}

\author{
Ekei Victor Ikpeme ${ }^{1^{\star}}$ \\ ${ }^{1}$ Animal Genetics and Genomics Unit, Department of Genetics and Biotechnology, University of \\ Calabar, PMB 1115, Nigeria.
}

Author's contribution

The sole author designed, analysed, interpreted and prepared the manuscript.

Article Information

DOI: $10.9734 / A R R B / 2021 / v 36 i 330348$

Editor(s):

(1) Prof. Jean-Marie Exbrayat, Université Catholique de Lyon, France.

Reviewers:

(1) Daniela Siel, University of Chile, Chile. (2) B. Balamurugan, Banaras Hindu University, India. Complete Peer review History: http://www.sdiarticle4.com/review-history/65406

Original Research Article

Received 06 January 2021

Accepted 12 March 2021

Published 30 March 2021

\begin{abstract}
This research work was carried out to evaluate the immune response of 3 turkey strains to salmonella and Newcastle vaccines measured via antibody titre. The study deployed a total of 120 poults (40 black, 40 white and 40 lavender) strains. To ascertain the initial antibody titre of all the birds, blood samples were obtained from their wing veins immediately after acclimatization for salmonella and Newcastle antibody titre. The test for salmonella and Newcastle antibody titre responses of the birds were performed using widal and haemagglutination inhibition (HI), respectively. The birds were divided into two broad groups tagged as $A$ and $B$, which represented Salmonella and Newcastle vaccines, respectively. Each group had 3 sub-groups denoting the 3 strains of turkey used for the study. After vaccination, blood samples were collected from all the birds at 3 and 5 days for laboratory assessment of antibody titre response. The results showed that there was significant increase $(p<0.05)$ in the antibody titre response of all the turkey strains after vaccination. Results obtained on the time of exposure of the birds to vaccine revealed that higher antibody titre values were obtained from the black and white turkey strains at 3 days than at 5 days after administration of Newcastle vaccine, except in the lavender strain, which had higher titre value at 5 days after Newcastle vaccination. Following administration of salmonella vaccine, black and lavender strains had statistically higher antibody titre response (2.03 and 2.10 mean $\log _{\mathrm{e}}$ widal, respectively) than white strain (1.86 mean $\log _{e}$ widal). Similarly, the black strain also had higher antibody titre value when Newcastle vaccine was administered (2.35 mean $\left.\log _{\mathrm{e}} \mathrm{HI}\right)$ followed by
\end{abstract}


lavender (1.99 mean $\left.\log _{e} \mathrm{HI}\right)$ and white strain (1.71 mean $\left.\log _{e} \mathrm{HI}\right)$. Black strains showed more antibody titre response and by implication, stronger immunity to Salmonella and Newcastle vaccines. More importantly, the differential response of the 3 turkey strains to vaccine could give turkey breeders the choice of selection of turkey breeds for disease resistance breeding.

Keywords: Turkey; widal; haemoglobin inhibition; vaccine; titre and antibody.

\section{INTRODUCTION}

In Africa and other developing countries, food insecurity has been a major challenge to many families. Both government and non-governmental organizations are devising ways to tackle this problem and despite this, eradication of hunger in these regions is yet to reach a significant stand point. Currently, the trend in research is identifying accessible and affordable sources of food and propagating them to combat food insecurity. Accessible protein sources are top targets in the fight against protein deficiency, a major contributing factor to malnutrition and the leading cause of death in children younger than five years [1]. Animal protein has been identified as a good source of protein that can supplement the human daily protein required for a healthy living. The myriad of animal protein sources, turkey (Meleagris gallopavo) remains a good choice with optimum quality and quantity of amino acid [2]. Among poultry, turkey has been pointed out with many economic and nutritional values. It is the second largest contributor to the world's poultry meat production after chicken [3]. Turkey birds do not require any special care to raise and are less prone to diseases than chicken [4]. Turkey has large size, high breeding performance and live mass compared to other poultry [5]. Turkey meat has high protein content with low fat which makes it good for people with high cholesterol [6]. The nutritional value of turkey meat and egg is hinged upon digestibility and the high content of essential amino acids [7]. Also, turkey meat contains vitamin B, phosphorus and mineral that play important part in maintaining healthy organs of the human body [8]. In 2016, the global turkey market made a remarkable rise by 9 percent to 6.2 million tonnes due to increased commercial farming [9]. The rise in living standard, rapid urbanization and increased awareness of the need to consume low fat foods by the growing global population have led to a significant increase in production and consumption of turkey meat across the world over the last decade [9].

Nigeria remains the most populated country in Africa with over 200 million individuals and there are projections that Nigeria's population will increase at an uncontrollable rate in the coming years with an estimation of over 400 million in 2050 [10,11]. The worry is that the projected increase in human population will most certainly place increased demand for food, and if there are no proactive measures to contend such demands, the level of hunger and malnutrition-related deaths will be alarming. Generally, poultry production including turkey has contributed remarkably to food availability, especially as a protein source, however, stringent problems such as disease outbreaks must be properly addressed to ensure improved production in the quest to meet up the high market demands. Salmonelosis has been one challenging disease affecting poultry birds. The causative agent of this disease is a bacterium of the genus Salmonella, a group of varying bacterium species; Salmonella enterica and Salmonella bongori. It is one of the most prevalent food-borne diseases worldwide especially in tropical countries. In 2013 , a total of 82,694 confirmed human cases of Salmonelosis were reported in Europe and Salmonella was reported to cause the largest number of food-borne outbreaks [12]. In poultry, a host-specific Salmonella infections cause fowl typhoid and pullorum diseases that promotes economic losses in different parts of the world [13]. Salmonellosis is predominant in poultry birds characterized by weight loss, listlessness, swollen hock joint, weakness, pale head and mortality. About $20 \%$ of infected turkey is lost annually as a result of salmonellosis [14]. Newcastle disease (ND), a highly contagious viral disease is another major threat to the poultry industry globally [15]. It is caused by Newcastle disease virus (NDV), which has been designated as type 1 avian avula virus [16]. NDV affect approximately 236 species of domestic avian birds such as chicken, Turkey, goose, duck, pigeon as well as pets and free living birds [17]. Despite the advances made in diagnosis and prevention, avian diseases such as salmonellosis and NDV continue to exhibit negative impact on the poultry industry [18]. 
In order to mitigate the spread of these diseases among poultry birds and the transmission to humans, there is need to identify preventive measures. Although control measures are difficult to use effectively, however, proper vaccination can be deployed to reduce this epidemic in birds [19], reduce loss to farmers and infection spread to human population. On the frontline of the measures to mitigate the spread of avian diseases among turkey birds is the need to select disease resistance strains for breeding. Genetic resistance, as an intrinsic property, has been explored to select natural resistant poultry strain [20]. Selection of disease resistance strains in conjunction with other positively correlated economic traits for breeding enhance vigour in offspring and creation of pure breeds with important traits that guarantee the farmer's gains. Genetic selection for resistance to immunosuppressive diseases has shown promising results [21,22]. Thus, this study was focused on vaccinating different turkey strains with attenuated Salmonella and Newcastle vaccines to assess their antibody titre level with the objective of providing poultry farmers with information on selection choice for disease resistance breeding within our local settings.

\section{MATERIALS AND METHODS}

\subsection{Study Location and Experimental Birds}

This study was carried out in two Departments in the Faculty of Biological Sciences, University of Calabar, Calabar, Nigeria. The housing and vaccination of the birds were carried out in the Animal House, Department of Genetics and Biotechnology while the evaluation of antibody titre was performed in the Laboratory of the Department of Microbiology. Day-old turkeys used for this research (black, white and lavender) were purchased from Obasanjo Farm in Ota, Ogun State, Nigeria. A total of 120 poults were obtained with 40 poults per strain.

\subsection{Management of Experimental Birds}

The poults were raised in large-sized cages constructed to accommodate daily growth of experimental animals with natural ventilation. Prior to the arrival of the experimental animals, the cages were properly cleaned and disinfected with ethyl alcohol. The birds were allowed to grow for 3 weeks for acclimatization and were fed with grower mash and sterile water before randomization and vaccination. Proper hygiene was maintained by cleaning and changing of the beddings on daily routine.

\subsection{Randomization and Vaccination}

Experimental birds were randomized using the randomized complete block design (RCBD). They were divided into two broad groups designated as A and B. Group A birds were vaccinated with Salmonella while group B were vaccinated with Newcastle vaccines, respectively. Each group had 3 sub-groups representing the 3 strains of turkey with 20 birds per sub-group. To assess the initial antibody titre of all the experimental birds after acclimatization, $1 \mathrm{ml}$ of blood was collected via their wing veins using sterile needle and syringe for laboratory analysis before vaccination process. After a week, $1 \mathrm{ml}$ of Salmonella and Newcastle vaccines were administered to the respective groups via their wing veins. Blood samples were collected into EDTA bottles at 3 and 5 days after vaccination for laboratory assessment of antibody titre. Antibody titre for Salmonella was determined using widal test by tube agglutination while antibody titre for Newcastle was determined using haemagglutination inhibition (HI) test [23].

\subsection{Procedure for Widal Test}

All the samples under salmonella vaccine were subjected to widal test by tube agglutination to assess salmonella antibody across the turkey strains. Three rows containing 6 test tubes were carefully prepared for the three turkey strains. Double dilution of the test serum $(1: 10,1: 20$, $1: 40,1: 80,1: 160$ and 1:320) were prepared in all the rows with each tube containing $0.4 \mathrm{ml}$ of the diluted serum. $50 \mu$ of antigen $\mathrm{O}, \mathrm{H}, \mathrm{AH}$ and $\mathrm{BH}$ was added to each test tube, mixed thoroughly and incubated at $37^{\circ} \mathrm{C}$ for $24 \mathrm{hrs}$. Appropriate tubes were prepared for positive and negative controls as well. The pattern of agglutination was determine macroscopically using the magnifying lens and compared with the controls. Antibody titre was taken as the highest dilution of serum giving visible agglutination [19,24].

\subsection{Procedure for Hemagglutination Inhibition Test}

Haemagglutination inhibition $(\mathrm{HI})$ test was carried out according to the procedure of World Organization of Animal Health [23]. Two serial dilution of $25 \mu \mathrm{l}$ serum was made with phosphate-buffered saline (PBS) in V-bottomed 
microtitre plates up to $10^{\text {th }}$ well. $25 \mu$ of 4 haemagglutination units of Newcastle disease virus or antigen was added up to $11^{\text {th }}$ well. The plates were kept at room temperature for more than 30 minutes to facilitate antigen-antibody reaction. Then $50 \mu \mathrm{l}$ of $1 \%(\mathrm{v} / \mathrm{v})$ turkey red blood cell (RBC) suspension was added to each well. The $11^{\text {th }}$ well containing the antigen and RBCs served as the positive control while the $12^{\text {th }}$ well containing only RBCs served as the negative control. After gently mixing, the RBCs were allowed to settle at room temperature for 40 minutes and agglutination was assessed by tilting the plates gently. The samples showing peculiar central button shaped settling of RBCs were recorded as positive and maximum dilution of each sample causing agglutination inhibition was considered as the end point, which was used to estimate $\mathrm{HI}$ titire. The $\mathrm{HI}$ titre of each serum was expressed as reciprocal of the serum dilution.

\subsection{Statistical Analysis}

All data obtained from the titre measurement were subjected to the test of normality using the Shapiro-Wilk test. The data were confirmed as normally distributed before being subjected to two-way analysis of variance (ANOVA) using SPSS version 20.0. The least significant different test was used to partition variation in the mean values at $p<0.05$.

\section{RESULTS}

\subsection{Immune Response of Turkey Strains to Salmonella Vaccine}

The results obtained on response of the 3 turkey strains to Salmonella vaccine are presented in Table 1 and Fig. 1. Table 1 revealed that white turkey strain had the highest antibody titre value (1.06 mean $\log _{e}$ widal; $p<0.05$ ) before administration of vaccine was commenced while black and lavender strains had lower and statistically similar titre values $(p>0.05)$. The post vaccination results showed that there was increase in antibody titre response of the three turkey strains as compared to the response before vaccination. Black strain had the highest titre value (2.22 mean $\log _{\mathrm{e}}$ widal) followed by lavender (2.17 mean $\log _{\mathrm{e}}$ widal) and white strain (2.11 mean $\log _{\mathrm{e}}$ widal), which were all statistically different from each other $(p<0.05)$. There was a drop in the titre values across the 3 strains at 5 days after vaccination. The results of the pooled performance of the 3 strains of turkey to salmonella vaccine as presented in Fig. 1 showed that black and lavender strains had statistically higher mean antibody titre response $(p<0.05)$ than white strain.

\subsection{Immune Response of Turkey Strain to Newcastle Vaccine}

The measurements obtained on response of the different strains of turkey to Newcastle vaccine are presented in Table 2 and Fig. 2. It was observed that before administration of vaccine, the titre values were low in all the strains with the highest titre value from white strain $(0.90$ mean $\left.\log _{e} \mathrm{HI}\right)$. However, the post vaccination results showed that there were significant increase $(p<0.05)$ in the titre values across the three turkey strains Table 2 . The highest antibody titre value was obtained from black strain 3 days after vaccination (2.20 mean $\log _{e} \mathrm{HI}$ ) followed by lavender (1.84 mean $\log _{e} \mathrm{HI}$ ) and white (1.11 mean $\left.\log _{e} \mathrm{HI}\right)$. The trend in results showed decrease in antibody titre values across the three strains 5 days after vaccination, however, black strain still maintained the highest mean titre (1.77 mean $\left.\log _{e} H I\right)$. From Fig. 2, the mean antibody titre of the 3 turkey strains revealed a statistically higher value from black strain. On the other hand, no statistical difference was observed between the mean antibody titre response of white and lavender strains $(p>0.05)$.

\section{DISCUSSION}

The goal of a breeder is to enhance breed's performance in measures that will translate to tangible economic benefits. Enhancing the performance of farm animals such as poultry birds are composite task involving many correlated tasks that must be carefully harnessed for actualization of the breeding goal. Measures to control disease outbreak and its spread among poultry farms is one of such critical task and should be considered beforehand in any poultry breeding programme. This is because once there is a disease outbreak with access to any poultry farm, controlling the spread among poults may be very difficult and unrealistic. As such, one of the best measures to prevent outbreak and the spread of disease among farm birds is to introduce proactive practices such as routine vaccination into breeding objectives before stocking [25]. It was observed in our study that the level of antibody decreased with time across the three turkey strains giving the highest antibody titre response at 3 days post vaccination. This may be an indication that the 
efficacy of vaccine reduces with time after vaccination and as such, routine vaccination should be encouraged among poultry breeders. Proliferation of lymphocyte can occur as early as 2-3 days after primary or secondary vaccination $[26,27]$. It is possible that vaccination of the turkeys had caused some elevation in the lymphocyte that resulted in the immediate significant increase in the antibody titre response at 3 days than 5 days of the post vaccination results. The findings of this study is in agreement with the report by [15] that vaccination of turkey with Newcastle vaccine led to significant elevation in the $\mathrm{HI}$ titre. According to [28], the activity of vaccines decreases with time. The same assertion was also made by [29] that antibody titre level reduced in birds with time as the number of weeks increased. Several studies indicating an increase in the level of antibody following vaccination have also been reported in chicken $[19,30,31,32]$, which are in line with the present findings on turkey.

Table 1. Response of turkey strains to Salmonella vaccine at different times of exposure

\begin{tabular}{|c|c|c|c|}
\hline \multirow[b]{2}{*}{ Exposure time } & \multicolumn{3}{|c|}{ Turkey strains } \\
\hline & Black & White & Lavender \\
\hline Pre-vaccination & $0.60^{b} \pm 0.04$ & $1.06^{\mathrm{a}} \pm 0.05$ & $0.64^{b} \pm 0.04$ \\
\hline 3 days post- vaccination & $2.22^{a} \pm 0.52$ & $2.11^{\mathrm{c}} \pm 0.59$ & $2.17^{b} \pm 0.35$ \\
\hline 5 days post- vaccination & $2.17^{\mathrm{a}} \pm 0.52$ & $1.89^{c} \pm 0.38$ & $2.18^{\mathrm{a}} \pm 0.45$ \\
\hline
\end{tabular}

Table 2. Response of turkey strains to Newcastle vaccine at different times of exposure

\begin{tabular}{|c|c|c|c|}
\hline \multirow[b]{2}{*}{ Exposure time } & \multicolumn{3}{|c|}{ Turkey strains } \\
\hline & Black & White & Lavender \\
\hline Pre-vaccination & $0.83^{b} \pm 0.40$ & $0.90^{\mathrm{a}} \pm 0.034$ & $0.68^{\mathrm{C}} \pm 0.01$ \\
\hline 3 days post- vaccination & $2.20^{\mathrm{a}} \pm 0.62$ & $1.11^{\mathrm{c}} \pm 0.72$ & $1.84^{\mathrm{b}} \pm 0.93$ \\
\hline 5 days post- vaccination & $1.77^{\mathrm{a}} \pm 0.31$ & $1.48^{\mathrm{b}} \pm 0.81$ & $1.39^{c} \pm 0.76$ \\
\hline
\end{tabular}

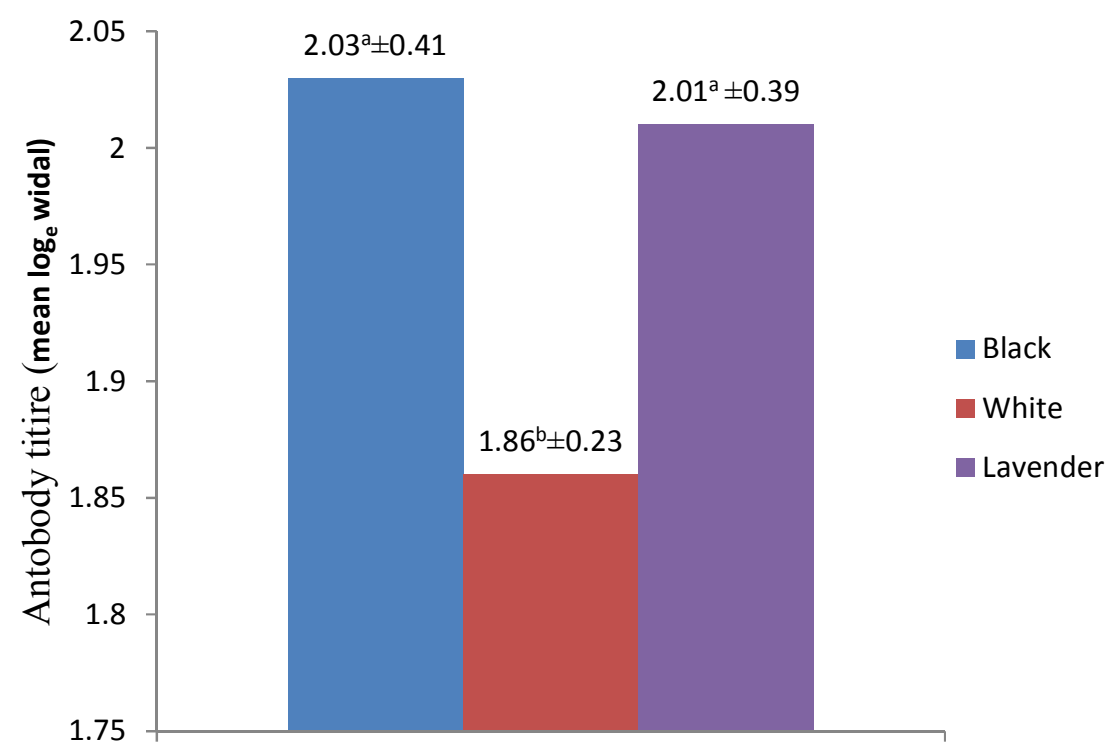

Turkey strains

Fig. 1. Mean titre response of 3 turkey strains to salmonella vaccine 


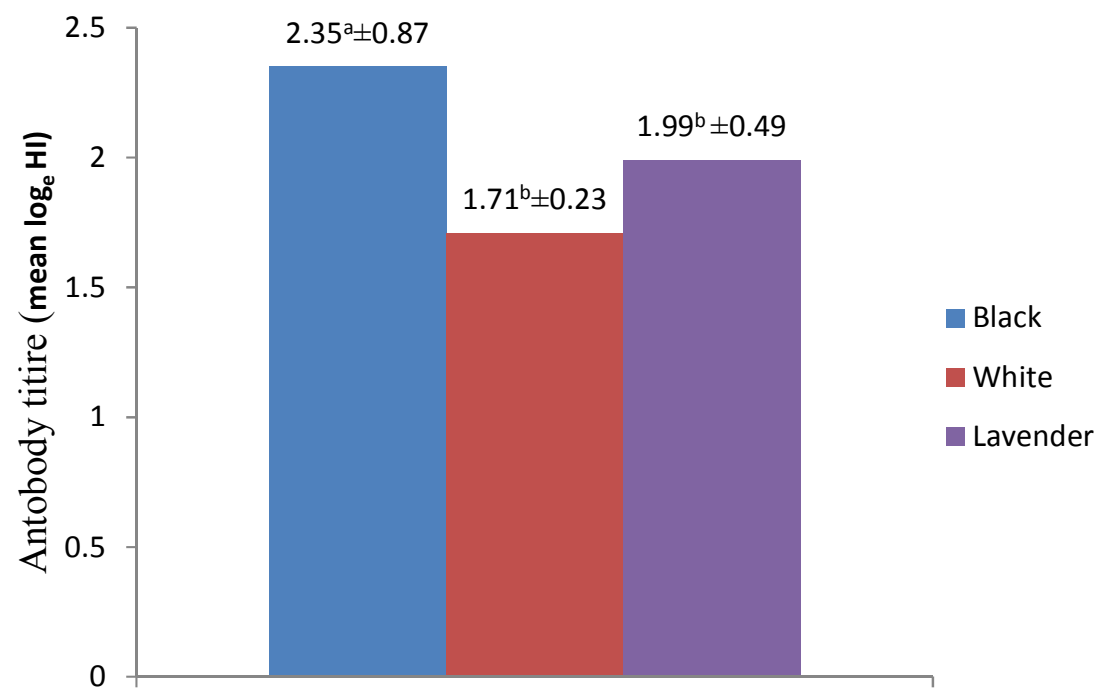

Turkey strains

Fig. 2. Mean titre response of 3 turkey strains to Newcastle vaccine

The monitoring of successful vaccination in flocks demonstrated by an elevation in the antibody titre within few days is a key parameter for assessing herds immunity and critical vaccination coverage $[15,33,34]$. Such monitoring is very useful in disease resistance breeding as it can be used as a tool for selection of breeding stock. Thus, the results obtained at 3 and 5 days post vaccination is a clear indication to encourage routine vaccination by turkey breeders and farmers since immunity may be weaken after a long period of vaccination.

Susceptibility to virus varies among different avian species and such variations in the level of immune response among different species and populations can be attributed to many factors including genetic background, environmental factors and virus strain [16,18]. Remarkably, vaccination of the turkey strains in this study produced differential response in the level of antibody titre by all the strains, indicating some level of variation in their immunity. Although the white strains of turkey produced the highest antibody titre before vaccination with both salmonella and Newcastle vaccines, their antibody titre were significantly reduced after vaccination. Black strain was consistent in eliciting a higher antibody titre response when either salmonella or Newcastle vaccine was administered followed by lavender while white strain was the least. These findings suggest that the black strain of turkey may be more resistant to salmonella and Newcastle outbreaks; and may also have been better adapted to the local environment where they were raised during this experiment. By implication, the black strain may give a better choice of selection for disease resistance breeding within similar environments.

Variation in response to vaccination is majorly due to the variation in immune response genes such as major histocompatibility-MHC $[35,36]$. The severity of infection with NDV is determined by many different factors such as tissue tropism, efficiency of replication, concurrent diseases, and host resistance to the virus [37]. Some of the NDV response traits are known to have a component of genetic control [38]. The differential response in antibody titre of the 3 turkey strains may therefore be an indication of the variation in their immune response genes. Importantly, the level of expression of such genes following vaccination may vary among turkey strains, which may be the reason behind the significant variations in antibody titre response of the turkeys observed after vaccination. This may also explain why the white strain only showed high antibody titre before vaccination but significantly reduced in the post vaccination results. These findings corroborate the report of [39] that viral infection of turkeys inform of vaccine strongly influenced their immune system leading to significant increase in the percentage of $\mathrm{CD}^{+}$cells. Similar reports were also made by $[40,41]$. The amount and diversity of antibodies correlates to the strength of the body's immunity [42]. It can be said 
therefore that the significantly high amount of antibody titre measured in the black turkey strain following salmonella and Newcastle vaccinations are an indication of their strong immunity compared to lavender and white strains.

\section{CONCLUSION}

Apparently, from the results of the present study, the turkey strains have different levels of immune response to vaccine, however, black strains have greater immunity since they produced the highest titre response.

\section{ETHICAL APPROVAL}

Ethical care and handling of the experimental animals were observed at all times and the study was approved by the University of Calabar ethical committee. The experiments were carried out in accordance with the legislation and authorization by the University of Calabar ethical committee.

\section{ACKNOWLEDGMENT}

Author wish to acknowledge the staff of Animal House, University of Calabar, Calabar, for all the assistance they provided to ensure a smooth over process during this research.

\section{COMPETING INTEREST}

Author has declared that no competing interest exist.

\section{REFERENCES}

1. World Health Organization. Children: Improving survival and well-being. 2020; 7:50.

Accessed: $26^{\text {th }}$ February, 2021.

Available:https://www.who.int/newsroom/fact-sheets/detail/children-reducingmortality.

2. Ahmed T, Saeed SAM, Hussien, HA. Evaluation of poultry meat safety based on ISO 22000 as food safety management system. Pakistan Journal of Nutrition. 2013;12:121-129.

3. Aslam ML. Genetic control and variation in Turkey: Molecular insights in selection. $\mathrm{PhD}$. Dissertation. Wageningen University: Netherlands; 2012.

4. TNAU Agritech Portal. Animal husbandry. In. Coimbatore: Tamil Nadu Agriculture University; 2011.
5. Kumarbek A, Aidyn I, Almagul N, Eleonora O, Samat K, Nazerke M, Zhanibek Y. Comparative analysis of red and white turkey meat quality. Pakistan Journal of Nutrition. 2017; 16:412-416.

6. Biesalski HK. Meat as a component of a healthy diet- are there any risks or benefit if meat is avoided in the diet? Meat Science. 2005;70:509-524.

7. Jukna V, Klementaviciute J, MeskinyteKausiliene E, Peciulaitiene N, Samborskyte M, Ambrasunas L. Comparative evaluation of quality and composition of ostrich, turkey and broiler meat. Biotechnol. Anim. Husband. 2012; 28:385-392.

8. Baggio SR, Vicente $\mathrm{E}$, Bragagnolo $\mathrm{N}$. Cholesterol oxides, cholesterol, total lipid and fatty acid composition in turkey meat. J. Agric. Food Chem. 2002;50:5981-5986.

9. Ryan J. Global turkey meat market: key findings and insights. 2018;7:30.

Accessed: $26^{\text {th }}$ February, 2021.

Available:https://www.thepoultrysite.com/n ews/2018/05/global-turkey-meat-marketkey-findings-and-insights.

10. United Nations world population prospectsUnited Nations population estimates and projections. 2019;11:42.

Accessed: $10^{\text {th }}$ September, 2020.

Available:https://population.un.org/wpp/.

11. World Population Review. 2020;11:39.

Accessed: $10^{\text {th }}$ September, 2020.

Available:https://worldpopulationreview.co $\mathrm{m} /$ countries/nigeria-population.

12. Annemarie $P$, Angelina K, Ellen DA, Wilfrid VP, Lucas W. Phenotypic behavior of 35 Salmonella enterica serovars compared to epidemiological and genomic data. Procedia Food Science. 2016;7:53-58.

13. Rovelledo LT. Avian Salmonellosis, vaccines and immune mechanisms of protection. Bahia, Brazil: Salvador. 2012;47.

14. Nagaraja KV, Pomeroy BS. Coronaviral enteritis of turkeys (bluecomb disease). In: Calnek BW, Barnes HJ, Beard CW, McDougald LR, Saif YM. Diseases of poultry. $10^{\text {th }}$ ed. Ames: lowa State University Press; 1997.

15. Brujeni GN, Hassanzadeh M, Al-Karagoly $\mathrm{H}$, Tolouei T, Esmailnejad A. Evaluation of humoral immune responses to enterotropic lentogenic VG/GA vaccine of Newcastle disease in commercial turkey poults (Meleagris gallopavo). Acta Veterinaria Scandinavica. 2019;61(41):16. 
16. Alexander DJ. Newcastle disease and other avian paramyxoviruses. Rev Sci Technol Oie. 2000;9:443-55.

17. Kaleta EF, Baldauf C. Newcastle disease in free-living and pet birds. In: Newcastle disease. Springer. 1988;197-246.

18. Alexander DJ, Aldous EW, Fuller CM. The long view: A selective review of 40 years of Newcastle disease research. Avian Pathology. 2012;41:329-335.

19. Ikpeme EV, Ekerette EE, Efienokwu JN, Ozoje MO. Immune response of Nigerian chicken genotypes to salmonella and newcastle vaccines. Trends Applied Sci. Res. 2019;14:296-302.

20. Kaboudi K. Virus-induced immunosuppression in turkeys (Meleagris gallopavo): A review. Open Veterinary Journal. 2019;9(4):349-360.

21. Hoerr FJ. Clinical aspects of immunosuppression in poultry. Avian Dis. 2010;54(1):2-15.

22. Cazaban C. Immunosuppression in chickens - what is it?. Int. Poult. Prod. 2015;13:13-14.

23. World Organization of Animal Health (OIE). Manual of diagnostic tests and vaccines for terrestrial animals (mammals, birds and bees). $7^{\text {th }}$ edn. World Organization of Animal Health (OIE): France. 2012;2

24. Jahan N, Khatoon R, Mehrotra AS, Kumar S. Comparative evaluation of slide agglutination and widal tube agglutination test in detecting enteric fever among patients attending a tertiary care hospital in north India. Int J Res Med Sci. 2016; 4(10):4290-4296.

25. Stear M. OIE manual of diagnostic tests and vaccines for terrestrial animals (Mammals, Birds and Bees), 5th edn. World Organization for Animal Health 2004: Cambridge Univ Press. 2005;1,2.

26. Maraqa AD. Studies on the immune response to Newcastle disease virus in poultry. Retrospective Theses and Dissertations Paper. 1996;3:54.

Accessed $3^{\text {rd }}$ May, 2017.

Available:http://lib.dr.iastate. edu/cgi/viewcontent.cgi?article $=12164 \&$ co ntext=rtd.

27. Reynolds D, Maraqa A. Protective immunity against Newcastle disease: The role of cell-mediated immunity. Avian Diseases. 2000;145-154.

28. Hesse M, Stamm A, Weber R, Glünder G, Berndt A. Immune response of turkey poults exposed at 1 day of age to either attenuated or wild Salmonella strains. Vet. Immunol. Immunopathol. 2016;74:1-10.

29. Munir IW, Bryden LW, Husband JA. Evaluation of the efficacy of intrapertoneal immunization in reducing salmonella typhimurium infection in chicken. Poult. Sci. 1988;77:1874-1883.

30. Loa CC, Lin TL, Wu CC, Bryan T, Thacker HL, Hooper T, Schrader D. Humoral and cellular Immune responses in turkey poults infected with turkey corona virus. Poultry Science. 2001;80:1416-1424.

31. Kremer CJ, O'Meara KM, Layton SL, Hargis BM, Coke K. Evaluation of recombinant salmonella expressing the flagella protein flic for persistence and enhanced antibody response in commercial turkeys. Poult. Sci. 2011; 90:752-758.

32. Rahman MM, Sarker RD, Nooruzzaman M. Evaluation of serum antibody titer level against Newcastle disease virus in vaccinated broiler chickens. Ann Vet Anim Sci. 2017;4:94-8.

33. Van BM, Bouma A, Fabri TH, Katsma E, Hartog L, Koch G. Herd immunity to Newcastle disease virus in poultry by vaccination. Avian Pathol. 2008;37:1-5.

34. Khalifeh M, Amawi M, Abu-Basha E, Yonis IB. Assessment of humoral and cellularmediated immune response in chickens treated with tilmicosin, florfenicol, or enrofloxacin at the time of Newcastle disease vaccination. Poult Sci. 2009;88: 2118-24.

35. Horton R, Wilming $\mathrm{L}$, Rand $\mathrm{V}$, Lovering $\mathrm{RC}$, Bruford EA, Khodiyar VK, et al. Gene map of the extended human MHC. Nature Reviews Genetics. 2004;5:889-899.

36. Kennedy RB, Ovsyannikova IG, Haralambieva IH, O'Byrne MM, Jacobson RM, Pankratz VS, et al. Multigenic control of measles vaccine immunity mediated by polymorphisms in measles receptor, innate pathway, and cytokine genes. Vaccine. 2012;30:2159-2167.

37. Dortmans JCFM, Koch G, Rottier PJM, Peeters BPH. Virulence of newcastle disease virus: what is known so far? Vet. Res. 2011;42:122.

38. Rowland K, Wolc A, Gallardo RA, Kelly T, Zhou H, Dekkers JCM, et al. Genetic analysis of a commercial egg laying line challenged with Newcastle disease virus. Front Genet. 2018;9:326.

39. Tykałowski B, Śmiałek M, Koncicki A, Ognik K, Zduńczyk Z, Jankowski J. The 
immune response of young turkeys to haemorrhagic enteritis virus infection at different levels and sources of methionine in the diet. BMC Veterinary Research. 2019;15(387):2-11.

40. Suresh M, Sharma J. M. Pathogenesis of type II avian adenovirus infection in turkeys: In vivo immune cell tropism and tissue distribution of the virus. J Virol. 1996;70:30-6.
41. Koncicki A, Tykałowski B, Stenzel T, Śmiałek M, Pestka D. Effect of infection of turkeys with haemorrhagic enteritis adenovirus isolate on the selected parameters of cellular immunity and the course of colibacillosis. Pol $\mathrm{J}$ Vet Sci. 2012;5:215-20.

42. Barrow PA. The paratyphoid salmonellae. Rev. Sci. Tech. 2000;19:351-357.

(c) 2021 Ikpeme; This is an Open Access article distributed under the terms of the Creative Commons Attribution License (http://creativecommons.org/licenses/by/4.0), which permits unrestricted use, distribution, and reproduction in any medium, provided the original work is properly cited.

Peer-review history:

The peer review history for this paper can be accessed here: http://www.sdiarticle4.com/review-history/65406 